\title{
AKTIVITAS ANTIOKSIDAN EKSTRAK BERBAGAI HASIL OLAH UBI JALAR
}

\author{
Frida Dwi Anggraeni ${ }^{1}$, Umar Santoso ${ }^{2}$, dan M. Nur Cahyanto ${ }^{3}$ \\ ${ }^{1}$ Jurusan Teknologi Hasil Pertanian, Fakultas Pertanian, Universitas Widyagama Malang \\ ${ }^{2}$ Jurusan Teknologi Pangan, Fakultas Teknologi Pertanian, Universitas Gadjah Mada \\ ${ }^{3}$ Jurusan Teknologi Pangan, Fakultas Teknologi Pertanian, Universitas Gadjah Mada \\ frida_dwi@yahoo.co.id
}

\begin{abstract}
Abstrak
Penelitian ini bertujuan untuk mengidentifikasi penurunan aktivitas antioksidan dari ekstrak ubi jalar satsumaimo dan ubi merahyang diproses tanpa pemanasan dalam bentuk pati dan dengan pemanasan yang diproses menjadi keripik, digoreng dan dibuat tape. Penentuan total fenol dengan metode Folin Ciocalteu yang menggunakan standar asam galat dan evaluasi aktivitas antioksidan ekstrak ubi jalar dengan metode DPPH, yang ditunjukkan dengan penurunan absorbansi. Terdapat penurunan aktivitas antioksidan dan total fenol ekstrak satsumaimo atau ubi merah yang diproses dengan pemanasan dibanding tanpa pemanasan. Penurunan aktivitas antioksidan terbesar pada ubi jalar yang digoreng (44,7\% ikatan radikal DPPH). Semakin lama dan semakin tinggi suhu proses pemanasan menyebabkan penurunan dari aktivitas antioksidan.

Kata kunci : satsumaimo dan ubi merah, total fenol, aktivitas antioksidan, dan metode DPPH
\end{abstract}

\begin{abstract}
The objective of this research was to observe the decreasing of antioxidant activity from satsumaimo and red sweetpotato extract that have been processed without heating to be starch and with heating to be flake, fried, and tape. Determination of total phenolic with the Folin_Ciocalteu method, with a standar gallic acid and antioxidant activity evaluation of sweetpotato extract conducted by DPPH method, which shown by the degradation of sweetpotato absorbance. There was a decreasing of antioxidant activity of satsumaimo or red sweetpotato extract that have been processed without heating than with heating and it was paralel with total phenolic content. The highest decreasing of antioxidant activity was fried sweetpotato (44,7\% DPPH radical scavenging). The longer and the higher of heating temperature processing, caused the decrease of antioxidant activity.

Keywords : satsumaimo and red sweetpotato, total phenolic, antioxidant activity, and DPPH method
\end{abstract}

\section{PENDAHULUAN}

Buah dan sayuran merupakan sumber yang kaya akan fitokimia, seperti karotenoid, flavonoid, dan komponen fenolik lain. Penelitian mengindikasikan bahwa fitokimia tersebut, terutama polifenol, memiliki aktivitas pengikat radikal bebas yang tinggi, yang mana mendorong penurunan resiko dari penyakit kronis, seperti penyakit kardiovaskuler, kanker, dan juga penyakit syaraf. Radikal bebas terbentuk dalam tubuh manusia melalui respirasi aerobik, dan keberadaannya dalam bentuk superoksida, hidroksil, hidroperoksil, peroksil, dan radikal alkoksi. Diet yang kaya antioksidan dapat membantu tubuh dalam menetralkan radikal bebas. Oleh karena itu, sangat penting untuk konsumsi diet tinggi antioksidan, seperti buah dan sayuran, untuk menurunkan pengaruh yang membahayakan terhadap stres oksidatif (Kano et. al., 2005).
Tanaman merupakan sumber molekul pengikat radikal bebas yang melimpah, seperti vitamin, terpenoid, senyawa fenolik, lignin, tanin, flavonoid, alkaloid, koumarin, dan metabolit lain yang kaya akan aktivitas antioksidan. Oleh karena itu, perhatian khusus difokuskan terhadap penggunaan antioksidan, terutama antioksidan alami, untuk menghambat peroksidasi lipid, atau untuk menjaga melawan kerusakan akibat radikal bebas. Komponen fenolik terutama yang merupakan sumber alami pada tanaman mampu melindungi melawan kerusakan ROS dan radikal bebas yang berhubungan dengan berbagai penyakit (Nagmoti et.,al., 2012)

Beberapa penelitian dan studi baru - baru ini menyebutkan bahwa ubi jalar merupakan sumber vitamin A, vitamin C, fenolik dan antosianin. Menurut penelitian Teow et al. (2007), 
adanya korelasi yang tinggi antara metode FolinCiocalteu dan DPPH mengindikasikan bahwa kandungan total fenolik dapat digunakan sebagai indikator untuk mengetahui aktivitas hidrofilik antioksidan pada ubi jalar. Hal ini karena dalam ubi jalar tersebut banyak mengandung senyawa fenolik yang diketahui mempunyai sifat antioksidatif (Fennema, 1985).

Berdasarkan penelitian, untuk meningkatkan konsumsi ubi jalar Hatay Kirmizi diperlukan juga penganekaragaman dalam pengolahannya. Berbagai pengolahan ubi jalar yang sudah banyak dikembangkan, tidak hanya dikonsumsi dengan dikukus, direbus, atau digoreng, tetapi dapat juga diproses menjadi berbagai produk, seperti muffin, kue kering, biskuit, ataupun mie yang memiliki umur simpan lebih lama dan meningkatkan karakteristik dari produk tersebut. Ubi jalar jenis Hatay Kirmizi ini juga bisa diproses menjadi tepung, yang lebih stabil dan dapat digunakan sebagai pengental, antioksidan dan sumber pewarna dalam industri bubuk sup, snack, dan produk bakery ( Tokusoglu dan Yildirim, 2012)

Dalam pengolahan ubi jalar biasanya menggunakan proses pemanasan. Hubungannya dengan keberadaan senyawa antioksidan, tahap pemanasan ini diduga akan menyebabkan penurunan aktivitas antioksidan. Dalam penelitian ini akan dilakukan pengolahan ubi jalar menjadi berbagai macam produk olah yaitu ubi jalar goreng, ubi jalar keripik, dan ubi jalar tape, sehingga dapat diketahui cara pengolahan ubi jalar yang paling tepat untuk mempertahankan potensi antioksidatif dari senyawa antioksidan di dalam ubi jalar.

Pengolahan ubi jalar menjadi produk olahan diduga masih terdapat senyawa yang terkandung dalam bahan yang berperan sebagai antioksidan. Oleh karena itu pada penelitian ini bertujuan untuk mengetahui pengaruh pengolahan ubi jalar menjadi berbagai macam produk terhadap aktivitas antioksidan yang ditunjukkan oleh penurunan kemampuan pengikatan radikal bebas menggunakan metode DPPH $(\alpha, \alpha$ Diphenyl Picrylhidrazil).

\section{METODE PENELITIAN}

\section{Bahan penelitian}

Bahan yang digunakan dalam penelitian ini adalah ubi Merah dan ubi Jepang. Untuk ekstraksi adalah hexan, dan etanol. Sedangkan untuk analisa kimia adalah larutan DPPH 0,1 mM, reagen Folin_Ciocalteu 10\%, sodium carbonat $10 \%$, dan aquades.

\section{Alat Penelitian}

Peralatan yang digunakan dalam penelitian ini adalah cabinet dryer, ayakan 40 mesh, blender, gelas beker, magnetic stirrer, kertas saring whatman no. 2, corong pemisah, aluminium foil, neraca analit, gelas ukur, erlenmeyer, evaporator, cawan petri, botol gelap, lemari pendingin, tabung reaksi, vortex, propipet, pipet ukur, gelas ukur, sentrifuge inkubator, dan spektrofotometer.

\section{Prosedur Percobaan}

\section{Persiapan Sampel Ubi Jalar}

Pecobaan ini dimulai dengan pembuatan produk dari ubi jepang dan ubi merah yaitu variasi pengolahan menjadi goreng, keripik dan tape. Kemudian dilakukan pembuatan bubuk dari hasil olah ubi jalar tersebut yaitu dengan pengeringan dalam cabinet dryer pada suhu $60^{\circ} \mathrm{C}$ selama \pm 24 jam, kemudian penggilingan dengan blender kering, dan pengayakan dengan ayakan 40 mesh. Produk tersebut dibandingkan dengan ubi jalar mentah yang dibuat menjadi pati.

\section{Ekstraksi Antioksidan}

Sebanyak 25 gram sampel ditambahkan etanol dengan perbandingan 1 : 5 dan diaduk dengan magnetic stirrer selama 15 menit. Setelah itu dilakukan penyaringan dengan kertas Whatman no. 2 untuk mendapatkan filtrat. Filtrat yang diperoleh diuapkan dengan rotary evaporator selama 30 menit pada suhu $40^{\circ} \mathrm{C}$ sampai didapatkan ekstrak semi solid yang kemudian dilakukan penimbangan. Setelah itu dilarutkan dengan etanol hingga konsentrasi 10000 ppm. Untuk sampel bubuk keripik dan bubuk goreng dilakukan defatting terlebih dahulu dengan menggunakan hexan untuk menghilangkan sisa sisa minyak goreng yang masih menempel pada bubuk.

\section{Penentuan Jumlah Total Fenol}

Penentuan jumlah total fenol dilakukan dengan menggunakan metode Folin_Ciocalteu (Huang dkk, 2004). $1 \mathrm{ml}$ ekstrak fenol sampel konsentrasi $500 \mathrm{ppm}$ ditambah $1 \mathrm{ml}$ reagen Folin_Ciocalteu kemudian digojog sehingga 
tercampur. Dilakukan penyimpanan gelap pada suhu kamar selama 3 menit, kemudian ditambahkan $2 \mathrm{ml}$ sodium carbonat $10 \%$ dan digojog. Penyimpanan gelap pada suhu ruang dilakukan selama 30 menit kemudian dilakukan sentrifugasi karena pada campuran terdapat endapan. Kompleks biru yang terbentuk ditera pada absorbansi $680 \mathrm{~nm}$. Jumlah senyawa fenol dinyatakan sebagai $\mathrm{mg}$ ekivalen asam galat/g berat kering.

\section{Pengukuran Aktivitas Antioksidan dengan Metode DPPH}

Pengujian aktivitas antioksidan ekstrak ubi jalar dalam sistem DPPH dengan menggunakan DPPH $(\alpha, \alpha$, Diphenyl Picrylhidrazil) radical scavenging methode (Islam dkk, 2003). $1 \mathrm{ml}$ ekstrak fenol sampel dengan variasi konsentrasi $100 \mathrm{ppm}, 200 \mathrm{ppm}$, dan $500 \mathrm{ppm}$ ditambah $4 \mathrm{ml}$ DPPH 0,1 mM kemudian divorteks. Setelah itu dilakukan pengukuran absorbansi yang dilakukan setiap 2 menit selama 30 menit sehingga diperoleh data penurunan absorbansi. Pada kontrol perlakuan yang dilakukan sama hanya sampel diganti dengan etanol 99,5 \% dan untuk pembanding sampel diganti dengan BHA 100 ppm dan rutin $100 \mathrm{ppm}$. Persentase aktivitas penangkapan (ARA) radikal $\mathrm{DPPH}^{*}$ dihitung dengan menggunakan rumus :
$\% A R A=$ Absorbansi kontrol - Absorbansi sampel $\times 100 \%$ Absorbansi kontrol

\section{HASIL DAN PEMBAHASAN}

\section{Rendemen Ekstrak Ubi Jalar}

Rendemen ubi jalar dinyatakan dalam \% berat ekstrak per 100 gram berat bubuk ubi jalar. Dari Tabel 1 terlihat bahwa rendemen ubi jepang tape paling besar yaitu sebesar $8,92 \%$, sedangkan rendemen ubi jepang goreng paling kecil yaitu sebesar $1,01 \%$.

Tingginya rendemen dari suatu ekstrak tidak dapat diartikan bahwa ekstrak tersebut memiliki aktivitas antioksidan yang tinggi pula, karena jenis senyawa - senyawa antioksidan yang terkandung dalam masing - masing ekstrak berbeda - beda sehingga aktivitasnya juga tidak akan sama. Mungkin senyawa antioksidan dalam suatu ekstrak yang rendemennya tinggi memiliki aktivitas rendah atau sebaliknya senyawa antioksidan dalam suatu ekstrak yang rendemennya rendah bisa memiliki aktivitas yang lebih tinggi (pada konsentrasi yang sama).

\section{Tabel 1. Rendemen ekstrak ubi jalar}

\begin{tabular}{lll}
\hline Varietas & Hasil Olah & Rendemen (\%) \\
\hline Ubi Jepang & Pati & 4,30 \\
& Keripik & 2,58 \\
& Goreng & 1,01 \\
& Tape & 8,92 \\
\hline Ubi Merah & Pati & 4,16 \\
& Keripik & 1,62 \\
& Goreng & 4,02 \\
& Tape & 5,91 \\
\hline
\end{tabular}

\section{Total Fenol Ubi Jalar}

Dari Tabel 2 terlihat bahwa total fenol pada ubi merah mentah paling besar dan total fenol pada ubi jepang goreng paling kecil. Apabila dilihat dari varietasnya, total fenol pada ubi merah lebih besar dibandingkan total fenol pada ubi jepang. Hal ini menunjukkan bahwa kandungan senyawa fenol sebagai antioksidan pada ubi merah lebih besar dibandingkan dengan ubi jepang. 
Jurnal Teknologi Pangan Vol. 6 No. 2

Nopember 2015

Tabel 2. Total fenol ekstrak ubi jalar

\begin{tabular}{lll}
\hline Varietas & Hasil Olah & Total Fenol (mg GAE/100 gr bubuk ubi jalar kering) \\
\hline Ubi Jepang & Pati & $133,00 \pm 11,66$ \\
& Keripik & $102,24 \pm 15,73$ \\
& Goreng & $43,19 \pm 9,59$ \\
& Tape & $86,88 \pm 13,67$ \\
\hline Ubi Merah & Pati & $245,42 \pm 14,40$ \\
& Keripik & $146,80 \pm 31,79$ \\
& Goreng & $66,64 \pm 10,60$ \\
& Tape & $95,91 \pm 12,23$ \\
\hline
\end{tabular}

Sedangkan apabila dilihat dari pengolahan ubi jalar, total fenol pada ubi jalar pati $>$ keripik $>$ tape $>$ ubi jalar goreng. Dari hasil tersebut menunjukkan bahwa lama proses dan suhu pemanasan pada saat pengolahan ubi jalar sangat berpengaruh terhadap keberadaan senyawa fenol yang ada dalam bahan. Semakin lama proses pemanasan dan semakin tinggi suhu yang digunakan, maka senyawa fenol yang terkandung didalamnya semakin terjadi penurunan. Pada ubi jalar goreng yang melalui tahap penggorengan pada suhu lebih dari $100^{\circ} \mathrm{C}$ selama \pm 10 menit, memiliki total fenol paling kecil karena senyawa fenol dalam bahan paling banyak yang hilang. Sedangkan ubi jalar tape yang pada pengolahannya melalui tahap pengukusan \pm 30 menit dan keripik ubi jalar yang melalui tahap penggorengan dalam waktu yang relatif singkat, juga mengalami penurunan jumlah total fenol yang cukup tinggi.

Jika dilihat dari varietasnya, total fenol ubi merah yang memiliki daging buah berwarna oranye lebih tinggi dibandingkan total fenol ubi jepang yang memiliki daging buah berwarna putih. Hal ini sesuai dengan penelitian Rumbaoa et al (2009) yang menunjukkan bahwa varietas ubi jalar dengan daging buah berwarna ungu memiliki kandungan fenol yang paling tinggi, kemudian diikuti dengan ubi jalar dengan daging buah berwarna oranye, kuning dan kandungan fenol terendah pada ubi jalar dengan daging buah berwarna putih. Perbedaan kandungan fenolik diantara varietas yang dikarenakan perbedaan genotif, mempengaruhi akumulasi kandungan fenolik oleh perbedaan kuantitas sintesis dan juga tipe komponen fenol (Rumbaoa et. al. (2009).
Menurut Padda dan Picha (2008), senyawa fenol merupakan senyawa - senyawa yang sangat mudah teroksidasi dan dipengaruhi oleh cahaya dan suhu. Semakin lama proses pemanasan dan semakin tinggi suhu yang digunakan pada saat pengolahan, maka senyawa fenol yang berperan sebagai antioksidan semakin banyak yang hilang.

\section{Pengujian dengan DPPH "Radical Scavenging Method" \\ Aktivitas Antioksidan Ekstrak Ubi Jalar Varietas Ubi Jepang}

Aktivitas antioksidan ekstrak ubi jepang yang diolah tanpa pemanasan menjadi pati dan ubi jepang yang diolah menjadi keripik, goreng, dan tape dibandingkan dengan BHA dan Rutin 100 ppm disajikan pada Gambar 1 berikut ini. 


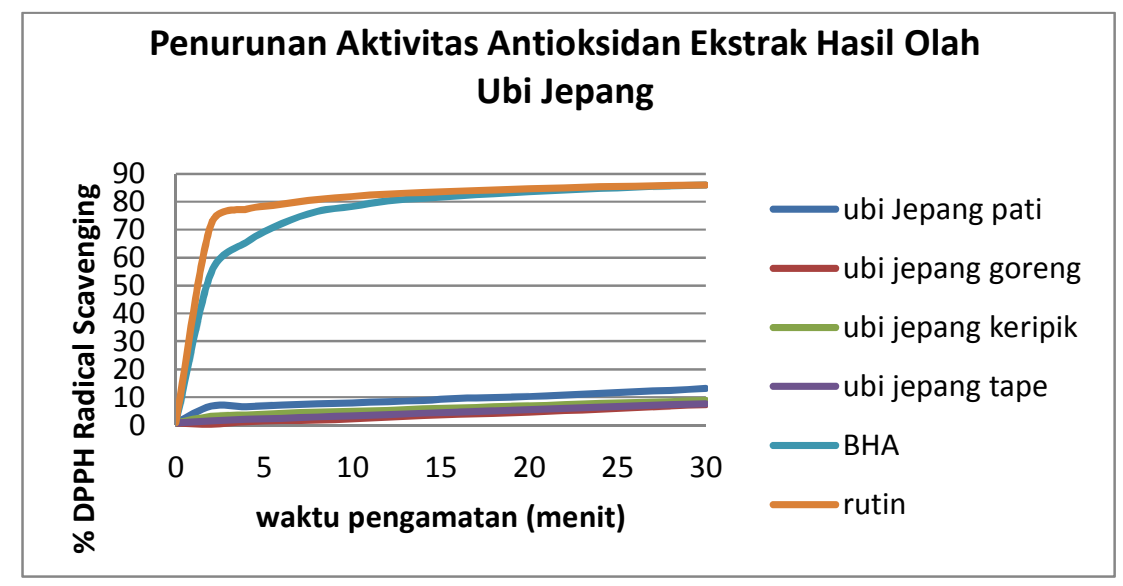

Gb 1. Penurunan aktivitas antioksidan ekstrak ubi jepang 100 ppm vs BHA dan Rutin 100 ppm

Dari Gambar 1 terlihat bahwa terdapat penurunan aktivitas antioksidan ekstrak ubi jepang yang diolah tanpa pemanasan menjadi pati dengan ubi jepang yang diolah dengan pemanasan menjadi keripik, tape dan ubi jepang goreng. Sedangkan aktivitas antioksidan ekstrak ubi jepang 100 ppm juga sangat berbeda nyata dibandingkan dengan antioksidan sintetik BHA dan antioksidan alami Rutin. Hasil pengujian menunjukkan aktivitas antioksidan pati ubi jalar konsentrasi 100 ppm setelah pengamatan 30 menit adalah 13,12\%. Sedangkan pada ubi jalar goreng, keripik, dan tape pada 100 ppm masing - masing mempunyai aktivitas antioksidan sebesar 7,37\%, $8,90 \%$, dan 7,66\%. Pembanding antioksidan sintetik BHA konsentrasi 100 ppm mempunyai aktivitas antioksidan $85,68 \%$ sedangkan antioksidan alami rutin $85,73 \%$. Jika dilihat dari hasil tersebut dapat diketahui bahwa potensi antioksidatif pada ubi jepang yang diolah dengan pemanasan mengalami penurunan dibandingkan ubi jepang yang diolah tanpa pemanasan. Hal ini dikarenakan selama pengolahannya melalui tahap pemanasan suhu tinggi, sehingga senyawa fenol yang terkandung di dalam ubi jalar banyak berkurang. Pada ubi jepang goreng terjadi penurunan aktivitas antioksidan paling besar yaitu 43,83\%. Hal ini dikarenakan pada pengolahannya melalui tahap penggorengan. Yang terjadi selama penggorengan adalah terjadi pertukaran antioksidan (dalam hal ini adalah phenolic) diantara minyak goreng dan makanan hasil penggorengan. Antioksidan dalam makanan hasil pengorengan akan larut dalam minyak goreng. Stabilitas makanan hasil pengorengan akan berkurang dengan cepat selama penyimpanan karena kehilangan senyawa antioksidan (Pokorny, 2001).

Aktivitas antioksidan pada ubi jepang yang diolah menjadi tape juga tidak berbeda nyata dengan ubi jepang goreng yaitu terjadi penurunan sebesar 41,62\%. Hal ini dikarenakan pada pengolahannya, dilakukan proses pengukusan selama 30 menit terlebih dahulu, sehingga kandungan senyawa fenol dalam ubi jalar telah banyak berkurang. Shobana dan Naidu (2000), yang melakukan penelitian mengenai aktivitas antioksidan pada herba menyatakan bahwa aktivitas antioksidan makin rendah setelah pemanasan 30 menit. Pemanasan yang terlalu lama kemungkinan dapat menyebabkan turunnya kemampuan senyawa - senyawa yang berfungsi sebagai penangkap radikal bebas. Sedangkan selama fermentasi (dalam hal ini setelah penambahan ragi tape) terjadi proses hidrolisis yang dapat menyebabkan pemecahan ester atau glikosida dari antioksidan phenolic menjadi aglycones. Biasanya dalam bentuk glikosida antioksidan, seperti quercetin dan myricetin, kemampuan antioksidannya lebih aktif daripada aglycones (Pokorny, 2001).

\section{Aktivitas Antioksidan Ekstrak Ubi Jalar Varietas Ubi Merah}

Penurunan aktivitas antioksidan ekstrak ubi jalar hasil pengolahan tanpa perlakuan pemanasan menjadi pati dan dengan perlakuan pemanasan menjadi keripik, goreng, dan tape ubi jalar pada konsentrasi 100 ppm dengan pembanding BHA dan Rutin disajikan pada Gambar 2 berikut ini. 


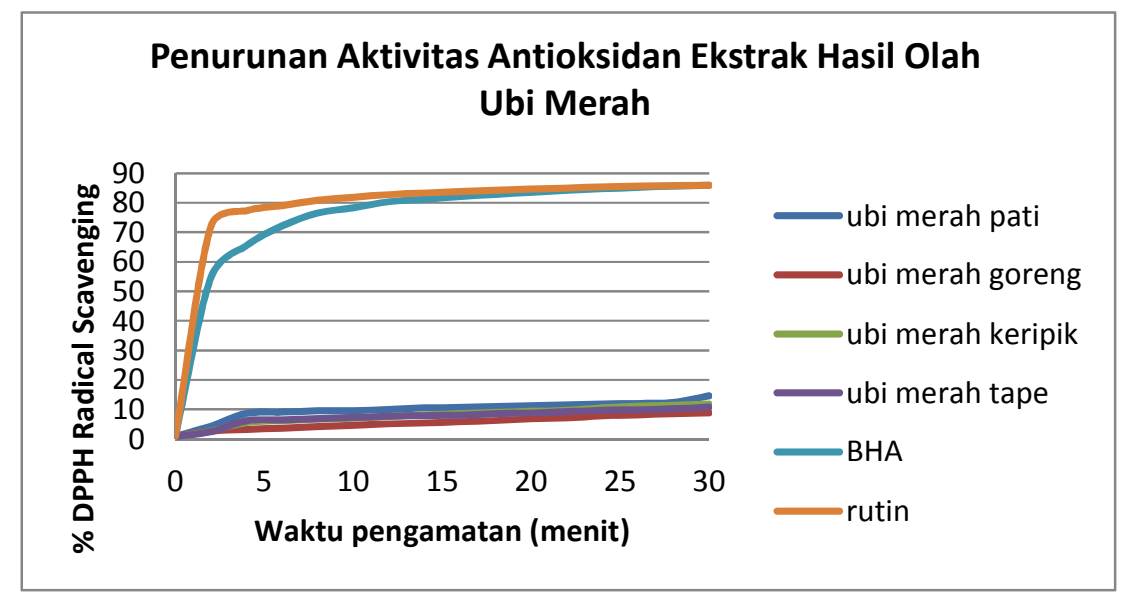

Gb 2. Penurunan aktivitas antioksidan ekstrak ubi jepang 100 ppm vs BHA dan Rutin 100 ppm

Dari Gambar 2 terlihat bahwa terdapat penurunan aktivitas antioksidan dari ekstrak ubi merah tanpa perlakuan pemanasan yang diolah menjadi pati dibandingkan dengan ubi merah setelah perlakuan pemanasan yang diolah menjadi tape, keripik, dan ubi merah goreng setelah pengamatan selama 30 menit. Seperti pada ubi jepang, ubi merah goreng juga terjadi penurunan aktivitas antioksidan paling besar yaitu sebesar $39,4 \%$, sedangkan pada tape dan keripik juga terjadi penurunan aktivitas antioksidan masing masing sebesar $26,29 \%$ dan $19,5 \%$.

Ubi merah memiliki potensi antioksidatif yang cukup tinggi. Pada ubi merah keripik hanya melalui tahap penggorengan yang hanya sebentar sehingga penurunan kemampuan fenol sebagai senyawa antioksidan juga tidak terlalu besar. Sedangkan pada ubi merah tape melalui tahap pengukusan selama 30 menit terlebih dahulu, sehingga penurunan kemampuan senyawa fenol dalam mengikat radikal bebas cukup besar.

Polifenol merupakan salah satu senyawa flavonoid yang terdapat pada tanaman. Menurut Tapiero et. al. (2002), flavonoid merupakan senyawa polar dan seperti semboyan lama "like dissolve like", maka flavonoid akan larut dalam pelarut polar seperti etanol, metanol, butanol, aseton, dimethyl sulphoxide, dimethyl formamide, air, dsb. Pada saat pengukusan, fenol yang terdapat pada ubi jalar terlarut dalam air, sehingga aktivitas antioksidan ubi jalar yang dikukus mengalami penurunan.

Gorinstein dkk (2005) dalam penelitiannya menunjukkan bahwa aktivitas antioksidan tertinggi adalah pada sampel segar diikuti sampel yang dipanaskan $100 \mathrm{C}$ selama 20 menit. Kemudian aktivitas antioksidan semakin menurun pada pemanasan selama 40 menit, dan yang terendah pada 60 menit pemanasan. Mereka menemukan bahwa proses pemanasan pada suhu $100^{0} \mathrm{C}$ lebih dari 20 menit menyebabkan semakin tingginya perbedaan (penurunan) komponen bioaktif, protein dan antioksidan dengan sampel segar. Sedangkan pada ubi merah goreng potensi antioksidatifnya paling kecil karena pada pengolahannya melalui tahap penggorengan \pm 10 menit, sehingga penurunan kemampuan senyawa antioksidan ubi merah dalam mengikat radikal bebas sangat besar.

Dari hasil penelitian tersebut, terdapat hubungan antara jumlah total fenol dalam ubi jalar dengan aktivitas antioksidan. Semakin rendah jumlah total fenol dalam ekstrak ubi jalar yang telah diolah, maka semakin rendah pula aktivitas antioksidannya. Aktivitas antioksidan pada ekstrak jaringan ubi jalar dari genotip yang berbeda berhubungan dengan konsentrasi komponen fenoliknya. Pada penelitian sebelumnya menunjukkan adanya korelasi yang kuat antara kandungan total fenol dan aktivitas antioksidannya (Padda dan Picha, 2008).

\section{Aktivitas Antioksidan Ekstrak Ubi Jepang dan Ubi Merah}

Penentuan aktivitas antioksidan yang dilakukan pada ekstrak ubi jepang dan ubi merah yang telah diolah menjadi produk tanpa pemanasan yaitu pati ubi jalar dan produk dengan pemanasan yaitu keripik ubi jalar, ubi jalar goreng, dan ubi jalar tape yang telah dikeringkan dalam cabinet dryer dan dihaluskan menggunakan blender, selanjutnya diekstrak menggunakan ethanol. 
Khusus untuk produk yang pengolahannya melalui tahap penggorengan, dilakukan defatting dahulu menggunakan hexan sebelum diekstrak untuk menghilangkan sisa minyak yang masih menempel. Selanjutnya disaring dengan kertas Whatman no. 2 dan filtrat diuapkan pelarutnya dengan menggunakan rotary evaporator. Grafik aktivitas antioksidan ekstrak ubi jepang dan ubi merah yang telah diolah menjadi pati ubi jalar, keripik ubi jalar, ubi jalar goreng, dan ubi jalar tape pada konsentrasi $500 \mathrm{ppm}, 200 \mathrm{ppm}$, dan $100 \mathrm{ppm}$ disajikan pada Gambar 3 berikut ini.

Dari Gambar 3 tersebut terlihat bahwa aktivitas antioksidan pada ubi merah lebih besar daripada ubi jepang. Sedangkan jika dilihat dari proses pengolahannya, aktivitas antioksidan pada produk yang telah mengalami proses pemanasan terjadi penurunan aktivitas antioksidan dengan penurunan yang terkecil yaitu keripik ubi jalar dan penurunan aktivitas antioksidan yang terbesar pada ubi jepang goreng. Berdasarkan penelitian C. C. Teow et.al (2007), ubi jalar dengan daging berwarna ungu memiliki aktivitas antioksidan paling besar, diikuti dengan ubi jalar dengan daging berwarna oranye, sementara ubi jalar dengan daging berwarna kuning dan putih memiliki aktivitas antioksidan DPPH terendah.

Pengukuran aktivitas antioksidan dengan metode DPPH ini menggunakan pembanding berupa antioksidan sintesis (BHA) dan antioksidan alami (rutin) serta kontrol yang hanya berisi etanol dengan larutan DPPH. Aktivitas antioksidan pada BHA dan rutin ini sangat efektif, yaitu sebesar $85,68 \pm 0,43 \%$ dan $85,73 \pm 0,25 \%$. Terbukti hanya dalam beberapa menit kedua antioksidan ini dapat mendegradasi dengan cepat warna larutan DPPH sehingga kondisi steady state dengan cepat dapat tercapai.

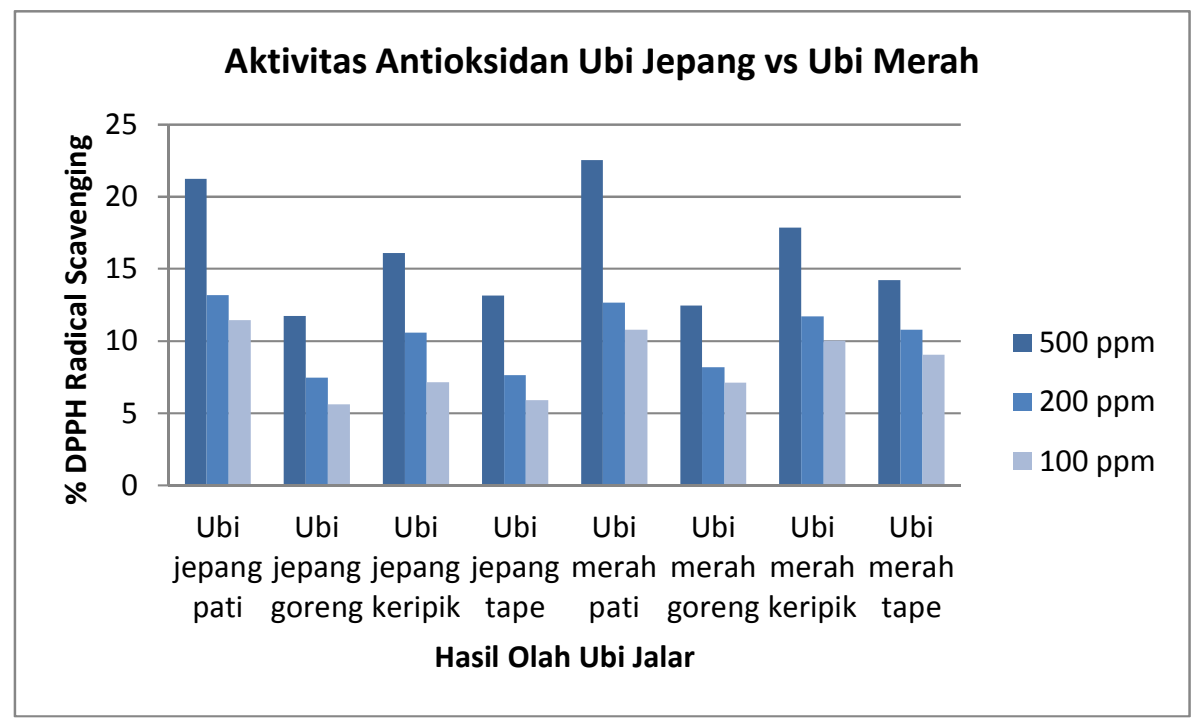

Gb. 3 Aktivitas Antioksidan Hasil Olah Ubi Jepang vs Ubi Merah pada konsentrasi 100 ppm, 200 ppm, dan $500 \mathrm{ppm}$

\section{KESIMPULAN}

Berdasarkan hasil penelitian dapat disimpulkan bahwa rendemen ekstrak ubi jalar yang terbesar adalah ubi jalar yang diolah menjadi tape. Akan tetapi tidak dapat diartikan bahwa aktivitas antioksidannya tinggi pula. Total fenol dan aktivitas antioksidan ekstrak ubi jalar baik pada ubi jepang maupun ubi merah yang diolah tanpa pemanasan yaitu pati lebih besar dibanding dengan ubi jalar yang diolah dengan pemanasan menjadi keripik, tape, maupun goreng, dan penurunnya lebih besar pada ubi jepang dibandingkan ubi merah. Semakin lama dan semakin tingginya suhu tahap pemanasan pada proses pengolahan, menyebabkan turunnya kemampuan senyawa - senyawa yang berfungsi sebagai penangkap radikal bebas, sehingga potensi antioksidatifnya juga semakin menurun. 


\section{DAFTAR PUSTAKA}

Fennema, O.R. (Ed)., 1985. Food Chemistry. Second edition. Marcel Dekker, Inc. New York

Gorinstein, S., Jerzy D., Hanna L., Maria L., Katarina N., Zenon J., Zofia Z., Henryk B., Boris S., Elena K., and Simon T., 2005. Comparison of the Bioactive Compounds and Antioxidant Potentials of Fresh and Cooked Polish, Ukrainian, and Israeli Garlic. J. Agric. Food Chem. 53, 2726-2732

Huang, D.J., Chun-der L., Hsien-Jang C., and yaw-Huei L., 2004. Antioxidant and Antiproliferative Activities of sweet potato (Ipomea batatas (L) Lam 'Tainong 57') Constituents. Botanical Bulletin of Academia Sinica, Vol.45

Islam, M.S., M. Yoshimoto, and O Yamakawa., 2003. Distribution and Physiological Function of Caffeoylquinic Acid Derivatives in Leaves of Sweetpotato Genotypes. J of Food Science. 68 (1) : 111-116

Juanda, D., dan B. Cahyono. 2000. Ubi jalar. Budidaya dan analisis usaha tani. Kanisius. 82 hal

Kano, M., T. Takayanagi, K. Harada, K. Makino, and F. Ishikawa. 2005. Antioxidative Activity of Anthocyanins from Purple Sweet Potato, Ipomea Batatas Cultivar Ayamurasaki. J. Biosci. Biotechnol. Biochem., 69 (5) : 979 988

Nagmoti, D. M., Khatri, D. K., Juvekar P., Juvekar A. R., 2012. Antioxidant Activity Free Radical-Scavenging Potential Of Pithecellobium Dulce Benth Seed Extracts. Free Radicals and Antioxidants 2(2):37-43

Padda, M. S., D. H. Picha, 2008. Effect Of Low Temperature Storage On Phenolic Composition And Antioxidant Activity Of Sweetpotatoes. J. Postharvest Biology and Technology $47: 176-180$

Pokorny, J., Nedyalka Y., dan Michael G., 2001. Antioxidant in Food: Practical Application. CRC Press, Boca Raton

Rumbaoa R. G. O, D. F. Cornago, and I. M. Geronimo, 2009. Phenolic Content And Antioxidant Capacity Of Philippine Sweet Potato (Ipomoea Batatas) Varieties. J. Food Chem. $113: 1133-1138$

Shobana, S. dan Naidu, K.A.2000. Antioxidant Activity of Selected Indian Spices,
Prostaglandins Leukot Essent. Fatty Acid, 62 (2) : $107-110$

Tapiero, H.,Tew, K.D., Nguyen Ba, G., dan Manthe, G., 2002. Polyphenols : Do They Play a Role in The Prevention of Human Pathologies, Biomed Pharmacother, $56: 200$ 207

Teow, C. C., V. D., Truong, R. F. McFeeters, R. L. Thompson, K. V. Pecota, and G. C. Yencho, 2007. Antioxidant activities, phenolic and bcarotene contents of sweet potato genotypes with varying flesh colours. J. Food Chem. 103 : $829-838$

Tokusoglu, O. , Yildirim, Z., 2012. Effects Of Cooking Methods On The Anthocyanin Levels And Antioxidant Activity Of A Local Turkish Sweetpotato [Ipomoea Batatas (L.) Lam] Cultivar Hatay Kirmizi: Boiling, Steaming And Frying Effects. Turkish Journal Of Field Crops, 2012, 17(1):87-90 